\title{
AMOUNT OF OPEN-FIELD DEFECATION, HOME CAGE DEFECATION AND FOOD AND WATER INTAKE IN MAUDSLEY REACTIVE AND NONREACTIVE STRAINS OF RATS
}

\author{
HĨROSHİ IMADA* \\ Department of Psychology, Kwansei Gakuin University
}

In many of the unpublished studies done in the present writer's laboratory, Hall's open-field (OF) test of emotionality has failed to show predictive validity. This lack of predictive validity of the test then raised two questions. The first is related to the possibility of predicting individual differences in emotional reactivity using a single-item test, depending mainly upon rats' defecation score. This question is specifically related to the problem of the sensitivity of defecation as a reliable index of emotional disturbance or fear. It has been shown that defecation could serve as an index of fear to some extent but it did not reflect degrees of emotional disturbance sensitively [HunT \& OTİs (3); IMADA $(4,5)]$. The second question is concerned with the possibility that $O F$ defecation may be confounded with a general defecatory tendency of rats. If the high defecators in the $\mathrm{OF}$ situation (a mildly stressful situation) were the high defecators in the home cage ( $\mathrm{HC}$, nonstressful situation), or vice versa, the OF defecation measure could not be regarded as an independent measure of emotional reactivity to stress. In the present writer's laboratory, TAMAKi (7), using 37 unselected strain of rats, obtained a significant positive correlation between the $\mathrm{OF}$ defecation and $\mathrm{HC}$ defecation $(r=.37, p<0.5)$.

In the present study the relationship between the OF defecation and

* The author is grateful to Mr. G. Clark (Department of Psychology, Institute of Psychiatry, University of London) for critically reading the manuscript. 
the $\mathrm{HC}$ defecation was studied using Maudsley Reactive (MR) and Nonreactive (MNR) strains of rats which are known to be different in emotional elimination [BRoAdHuRst(1)]. Other HC measures (e.g., amount of food and water intake) as well as OF measures were recorded.

\section{Method}

Subjects: Six males and six females from the 36th generations of the MR and MNR strains were used as subjects. Their age range and body weight are shown in rows 1 and 2 of Table 1 . In row 1, alphabet letters are used for the litter identification, the animals from the same litter being represented by the same letter.

Apparatus: The ordinary cages for housing rats and the standard OF $\lceil$ BROADHURST (1) J were used. The OF consisted of a plywood arena $32 \frac{3}{4}$ in. in diameter with white-painted walls $12 \frac{1}{2}$ in. high. The floor was divided into segments by lines so that one could measure the activity of rats in terms of number of segments traversed in a unit of time. The illumination at the floor level was approximately $165 \mathrm{fc}$ and the white noise of $78 \mathrm{db}$ was continuously sounded during the testing.

Procedure: Eight days before the measurement in the HC began, all $S$ s were transferred from group cages, in which they had been housed in groups of three, and housed singly. Under each cage, two sheets of brown paper towel were placed in a tray and the paper towels were changed every twenty four hours. Food and water were available ad libitum. Twenty four hours before the first measurement in the $\mathrm{HC}$ took place, food hoppers and water bottles were filled and the amount of each was recorded. Every twenty four hours, the paper towels were removed from the tray and the number and weight of fecal boluses and the amount of food spillage were measured. The procedure was repeated for four days in order to include one estrous cycle. After four days, the total amount of food and water consumed in four days was measured. With regard to the amount of food intake measure, the net amount was obtained by subtracting the total amount of spillage over four days from the total amount of food lost from the hopper in four days.

Four days after the last day of recording of the $\mathrm{HC}$ measures, the OF test was given in the standardized manner. The procedure for the standardized OF testing have been described in detail elsewhere [Broadhurst (1)]. Briefly, it consisted of 
Table 1. Summary of the Results

\begin{tabular}{|c|c|c|c|c|c|c|c|c|}
\hline & \multicolumn{3}{|c|}{ Males } & \multicolumn{3}{|c|}{ Females } \\
\hline & & & MR & MNR & signif. & MR & MNR & signif. \\
\hline 1) & \multicolumn{2}{|r|}{ Age and litter } & $\begin{array}{r}162-172 \\
\text { AABCCD }\end{array}$ & $\begin{array}{r}155-165 \\
\text { EEFFGG }\end{array}$ & & $\begin{array}{r}162-169 \\
\mathrm{ABBCDD}\end{array}$ & $\begin{array}{c}155 \\
\text { НHНHНH }\end{array}$ & \\
\hline 2 & $\mathrm{Bc}$ & ody weight & $\begin{array}{l}294.50^{*} \\
(14.78)\end{array}$ & $\begin{array}{l}227.67 \\
(11.95)\end{array}$ & $p<.001$ & $\begin{array}{c}181.67 \\
(8.83)\end{array}$ & $\begin{array}{r}163.50 \\
(8.16)\end{array}$ & $p<.01$ \\
\hline \multirow{4}{*}{ 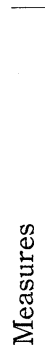 } & \multirow{4}{*}{$\underbrace{4}_{0}$} & $\begin{array}{l}\text { 3) Amount of } \\
\text { intake per } \\
\text { day }\end{array}$ & $\begin{array}{l}27.01 \\
(2.46)\end{array}$ & $\begin{array}{l}23.53 \\
(0.78)\end{array}$ & $p<.05$ & $\begin{array}{l}19.47 \\
(0.48)\end{array}$ & $\begin{array}{l}21.51 \\
(1.33)\end{array}$ & $p<.001$ \\
\hline & & 4) 3) $/ 2) \times 100$ & $\begin{array}{l}9.17 \\
(0.64)\end{array}$ & $\begin{array}{l}10.34 \\
(0.69)\end{array}$ & $p<.05$ & $\begin{array}{l}10.71 \\
(0.78)\end{array}$ & $\begin{array}{l}13.16 \\
(0.65)\end{array}$ & $p<.001$ \\
\hline & & $\begin{array}{l}\text { 5) Amount of } \\
\text { intake per } \\
\text { day }\end{array}$ & $\begin{array}{l}43.00 \\
(7.10)\end{array}$ & $\begin{array}{l}38.96 \\
(4.65)\end{array}$ & n. s. & $\begin{array}{l}30.63 \\
(2.85)\end{array}$ & $\begin{array}{l}43.08 \\
(3.58)\end{array}$ & $p<.001$ \\
\hline & & 6) 5) $/ 2) \times 100$ & $\begin{array}{l}14.67 \\
(2.78)\end{array}$ & $\begin{array}{l}17.18 \\
(2.48)\end{array}$ & n. s. & $\begin{array}{l}16.90 \\
(1.87)\end{array}$ & $\begin{array}{l}26.44 \\
(2.77)\end{array}$ & $p<.001$ \\
\hline \multirow[t]{3}{*}{ U: } & \multirow{3}{*}{ 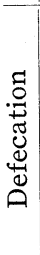 } & $\begin{array}{l}\text { 7) } \begin{array}{l}\text { Number of } \\
\text { boluses per } \\
\text { day }\end{array}\end{array}$ & $\begin{array}{l}53.58 \\
(2.55)\end{array}$ & $\begin{array}{c}58.83 \\
(6.67)\end{array}$ & n. s. & $\begin{array}{c}47.58 \\
(3.99)\end{array}$ & $\begin{array}{c}58.25 \\
(4.59)\end{array}$ & $p<.01$ \\
\hline & & $\begin{array}{l}\text { 8) Weight of } \\
\text { boluses per } \\
\text { day in grams }\end{array}$ & $\begin{array}{l}10.84 \\
(0.56)\end{array}$ & $\begin{array}{l}10.20 \\
(1.11)\end{array}$ & n. s. & $\begin{array}{c}7.27 \\
(0.76)\end{array}$ & $\begin{array}{c}8.65 \\
(0.42)\end{array}$ & $p<.01$ \\
\hline & & 9) 8) /2) $\times 100$ & $\begin{array}{l}3.68 \\
(0.17)\end{array}$ & $\begin{array}{c}4.51 \\
(0.72)\end{array}$ & $p<.05$ & $\begin{array}{c}4.00 \\
(0.38)\end{array}$ & $\begin{array}{l}5.30 \\
(0.37)\end{array}$ & $p<.001$ \\
\hline \multirow{3}{*}{ 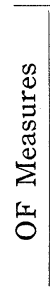 } & \multirow{3}{*}{ 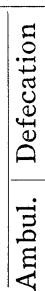 } & 10) $\begin{array}{l}\text { Number of } \\
\text { boluses per } \\
\text { day }(\mathrm{A})^{* *}\end{array}$ & $\begin{array}{c}3.92 \\
(0.37)\end{array}$ & $\begin{array}{c}0.58 \\
(1.30)\end{array}$ & $p=.004$ & $\begin{array}{c}3.21 \\
(0.88)\end{array}$ & $\begin{array}{c}0.00 \\
(0.00)\end{array}$ & $p=.002$ \\
\hline & & 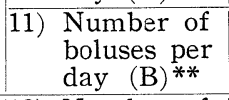 & $\begin{array}{c}4.63 \\
(0.37)\end{array}$ & $\begin{array}{c}0.58 \\
(1.30)\end{array}$ & $p=.002$ & $\begin{array}{c}3.58 \\
(0.91)\end{array}$ & $\begin{array}{c}0.00 \\
(0.00)\end{array}$ & $p=.002$ \\
\hline & & 12) $\begin{array}{l}\text { Number of } \\
\text { sections } \\
\text { traversed } \\
\text { per day }\end{array}$ & $\begin{array}{l}19.29 \\
(3.76)\end{array}$ & $\begin{array}{l}32.29 \\
(4.10)\end{array}$ & $\begin{array}{l}p<.001 \\
p=.002\end{array}$ & $\begin{array}{l}35.17 \\
(1.62)\end{array}$ & $\begin{array}{c}53.25 \\
(10.26)\end{array}$ & $\begin{array}{l}p<.01 \\
p=.002\end{array}$ \\
\hline
\end{tabular}

* The number in each cell are the arithemetic mean and corresponding standard deviation, the latter being shown in parenthesis. The $t$ tests (two-tailed) for independent groups were applied to all the data except those in rows 10 and 11. These data were subjected to Mann-Whitney $U$ tests. For row 12, both parametric and nonparametric tests were performed.

**In the present study, the number of fecal boluses eliminated in the OF, and in the bucket used to carry rats to and from the OF, were recorded. In row 10 the defecation scores in the OF (A) are presented, and in row 11 the combined defecation scores (B) are given. 
placing $S$ s individually in the OF for two min. per day for four days. The number of fecal boluses eliminated and the total number of sections traversed were recorded. In the present experiment the procedure was different from the standardized procedure in one respect, i. e., there was an interval of 48 hours between the first and the second trials rather than an interval of 24 hours*. The temperature of the animal colony was kept approximately at $70^{\circ} \mathrm{F}$ all the time.

\section{Results and Discussion}

The results are summarized in Table 1 . As shown in rows 10 and 11 , for both sexes the MR showed significantly more defecation in the OF than the MNR. For the MNR, when both sexes were combined, 11 out of 12 rats did not defecate at all in the OF test. As to the $\mathrm{HC}$ defecation, there was no evidence that the MR defecated more in the $\mathrm{HC}$ than the MNR (rows 7 and 8 ). The MNR, or the low OF defecators, rather tended to eliminate greater number of boluses than the MR. This was especially marked in females and there were significant differences between the two strains both in the number and weight of boluses eliminated in the HC. Unfortunately a generalization from this fact is limited in the light of the fact that all the females of the MNR were from a single litter.

It will be noted from rows 7 and 8 that the average weight of a single bolus was heavier in the MR males than in the MNR males $(p<.01)$, due presumably to a marked difference in the body size of the two strains (see row 2). RUEGAMER et al. (6) have shown that weanling male albino rats with extrahandling showed significantly more body weight gain and eliminated fewer boluses in the $\mathrm{HC}$ than rats which were not handled at all in infancy. Although Ruegamer et al. (6) interpreted this observation as indicating better food utilization in the extrahandled rats, the interpretation may not be legitimate unless the weight (rather than the number) of boluses were recorded.

The other results concerning the MR and MNR were generally in

* This was due to the noises caused by the construction of the building on the second day of the OF testing. 
line with the previous findings. To summarize: 1) For both sexes, the MR were significantly heavier in body weight than the MNR [BRoadhurst (1), Yatkin \& Eysenck (9)]; 2) For both sexes, the MR ambulated significantly more than the MNR in the OF situation [Broadhurst (1), Broadhurst \& Eysenck (2)]; 3) For both sexes, the metabolic rate was higher in the MNR than in the MR [WATson (8) ]. More specifically, the MNR took more food and defecated greater amount of boluses than the MR relative to the body weight (rows 4 and 9 ).

\section{Summary}

The number and weight of fecal boluses in the home cages (HC) of Maudsley reactive (MR) (6 males and 6 females) and nonreactive (MNR) (6 males and 6 females) strains of rats were recorded for four days. They were also given the open-field (OF) test of emotionality. The MR rats defecated significantly more in the OF situation than the MNR rats, but there was no tendency for the MR rats to defecate more in the $\mathrm{HC}$ than the MNR rats. The OF defecation score proved to be independent of the $\mathrm{HC}$ defecation score. Other $\mathrm{HC}$ measures and OF measures were recorded. Generally the results were in line with the previous findings.

\section{References}

1. Broadhurst, P. L. Applications of biometrical genetics to the inheritance of behavior. In H. J. Eysenck (Ed.), Experiments in personality. Vol. 1, London: Routledge and Kegan Paul, 1960.

2. Broadhurst, P. L. and Eysenck, H. J. Interpretations of exploratory behavior in the rat. In H. J. Eysenck (Ed.), Experiments in motivation. London: Pergamon Press, 1964.

3. Hunt, H. F. and Oris, L.S. Conditioned and unconditioned emotional defecation in the rat. J.comp. physiol. Psychol., 1953, 46, 378-382.

4. ImADA, H. Relationship between suppression of drinking behavior and defecation in shock situation (rat). Ann. Anim. Psychol., 1966, 16, 141-145. 
5. IMADA, H. Emotional reactivity and discriminability in four strains of rats (MR, MNR, RHA and RLA). Paper read at the 34th Annual Convention of the Japanese Psychological Association, 1970.

6. Ruegamer, W. R., Bernstein, L., and Benjamin, J.D. Growth, food utilization, and thyroid activity in the albino rat as a function of extrahandling. Science, 1954, 120, 184-185.

7. TAMAKI, Y. An experimental study of emotionality of rats. Unpublished MA thesis, Kwansei Gakuin University, 1970.

8. Watson, R. H. J. Constitutional differences between two strains of rats with different behavioural characteristics. In A. Jones, and B. Stokvis (Eds.), Advances in psychosomatic medicine, Vol. 1. Basel: Karger, 1960.

9. Y Y of the interaction of two drives. In H. J. Eysenck (Ed.), Experiments in motivation. London: Pergamon Press, 1964.

(Received August 25, 1970) 